\title{
THE INCREASE OF STUDENTS' ARABIC READING SKILLS THROUGH THE APPLICATION OF SQ4R LEARNING TECHNIQUE
}

\author{
Nova Erlina \\ UIN Raden Intan Lampung \\ novaerlina@ radenintan.ac.id
}

\begin{abstract}
The aim of this research is to increase the Arabic reading skills of the students in the forth semester of the Department of Arabic Language Education, Academic Year 2017 in understanding Arabic texts through the application of SQ4-R learning technique. This research is an action research with qualitative approach. Methods for data gathering: observation, interview, portfolio, reading comprehension test, and field record. Data were analyzed qualitatively by reducing and presenting them as well as withdrawing conclusion.

Research findings: The application of SQ4-R endured modification through the addition of a learning stage, namely stage on finding vocabulary and meaning in dictionary that happened post survey stage. Through this action research, SQ4-R was modified into SVQ4-R. The result of this research shows increase on the students' skills in which initially they simply reached literal comprehension with class' average score 48 prior to the action, 69.7 in the $1^{\text {st }}$ cycle, 77.68 in the 2 nd cycle, and 78.22 in the $3 r d$ cycle. The average score on interpretative comprehension, prior to the action, did not appear, in the 1st cycle, 67, in the 2nd cycle 68.4, and in the 3rd cycle, 73. The average score on applicative and critical comprehension, prior to the action did not appear in the 1st cycle, 64.3, in the 2nd cycle, 70.4, and in the 3rd cycle, 78.09 .
\end{abstract}

Keywords: Arabic Reading Skills, SQ4-R, learning technique, and action research

Reading is a process to comprehend a written text. Reading includes recognizing and comprehending what is written, particularly the words. According to Elyzabeth S. Pang, et. al (2003:6), symbol recognition is a process of accepting the symbols and symbol comprehension is a process of understanding them (written text).

Reading is an important part in one's life. Thus, it is essential to develop reading skills and habit to enhance one's knowledge and skills in attaining reading goals.

Arabic reading skills are paramount, particularly for Islamic university students as Arabic is the language of Quran and used in scientific writing. Mostly science, specifically Islamic science, is written in Arabic. It is also one of international languages. Therefore, Arabic reading skills is crucial to be enhanced through a programed learning so that learning goals can be successfully achieved.

The skills to read Arabic texts are the key to knowledge, in fact the key to a successful learning, especially for Islamic university students. However, in reality not all students in this 
research had the skills. Most of them were unable to read Arabic texts well. Their ability to comprehend written texts was still low.

The latter result was shown during Arabic reading class, mostly they encountered problems in comprehending the text. They had limited vocabularies, knowledge on morphology and semantic (knowledge on sorf), as well as diction and word meaning in context (knowldge on $n a h w u$ ). This situation occured to $50 \%$ of all research subjects. Even though there were some of them who were able to understand the text, it was still literal comprehension.

Students' participation in learning was also low. They were passive and not quick enough to respond the learning activity. When they found a new word in the text, they merely waited for the information from the lecturer. If a student was asked to find the meaning, others were passively waiting (Learning observation on March 29, 2013).

Their ability to comprehend Arabic texts are as follows. From 22 students, only 10 students received comprehension scores above 55, and they still reached literal comprehension. The rest of the students acquired scores under 55; (pre-action initial test, September 27, 2012).

To overcome this issue, well-planned and systemized efforts to increase students' Arabic reading skills were needed.

Thus, the researcher conducted an action research by applying SQ4-R learning technique in comprehending Arabic reading texts. SQ4-R technique is survey, question, read, recite, rephrase or rewrite, review. This technique is one of the reading techniques that is innovative and challing students to learn independently, actively, and efficiently. Through this technique, one can gain a lot of advantages, some of which are information, and skills in reading, listening, speaking, as well as writing.

\section{A. Arabic Reading Skills}

a. The Nature of Reading Skills

Abdul Majid al-Araby (1981:101) explains that reading is crucial for university students because reading is one of the skills needed to read literature and scientific books, analyze one's culture and thought, and conduct research in various fields.

Skills meant in this research are the skills to pronounce fluently and correctly the symbols of sounds in correspondence with their Arabic text and to understand it.

According to Nuttal $(1989: 2,251)$ reading is one of the activities to codify, interpret, identify, talk, pronounce, react, and give meaning. Reading is a thinking process to rationalize a text, contains one's way of thinking, rules and regulation, analysis, cause and effect, problem solution, and not merely identify and understand the meaning of words.

In Arabic, the word read is equivalent to the word قر

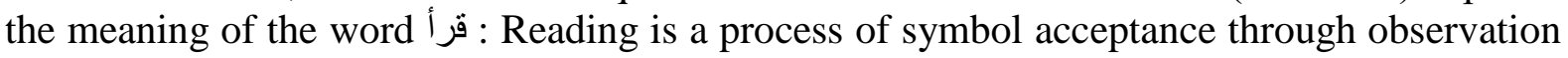
(also known as perception), where the thought of the writer and reader meet (interaction process) with its application is depicted in the future. Reading can mean an activity of recognition, comprehension, criticism, a brain activity that desires the entrance of all aspects of human ability.

Reading is a process to comprehend texts, particularly Arabic texts. Soedarso (2004:7273), points out that reading process is initiated from comprehending the text, validating the references, interacting with the writer; accepting and rejecting the written information. 
Reading needs to utilize imagination, the ability to observe and remember previous knowledge, as well as language knowledge. Comprehension is influenced by a number of internal factors, such as perception, belief, motivation, and problem solving strategy (Baker and Brown, Block and Pressley, Pearson, Farstrup and Samuels, Ruddell, Ruddell and Singer in Linda and Soffos: 2005: 6).

It can be concluded that reading is a process involving all aspects of human ability in a joint effort of cognitive action to build meaning in making use imagination, observation, (written) symbol pronunciation,memorization, schemata, and language knowledge.

\section{b. Types of Reading Skills}

Arabic reading skills consists of four types of reading, first, reading aloud ( لقراءة

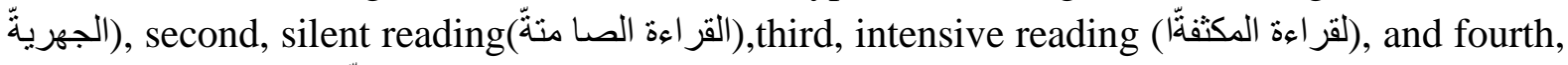
extensive reading (لقراءة الموسعةًاة). In this research, the skill enhanced is intensive reading (القر اعة المكثنة).

The limitation is due to urgency as the skill is very crucial for students' continuity of study.

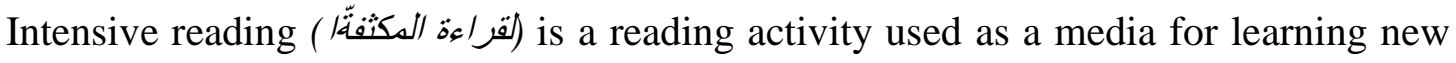
words or idioms. The learning materials chosen are a little bit higher than students' ability, The materials are usually based on language learning program or curriculum.

The aim of this intensive reading is to enhance the intensification of Arabic learning and students' ability to read in the language. The extensive reading happened in the class under the supervision of lecturer or teacher. The learning process of the reading occurred by providing excersices that contained explanation of difficult words, new idioms, and extended students' vocabularies as well as developed their ability in discussing, analyzing, and understanding knowledge.

\section{c. Reading Comprehension}

While reading, the interaction between reader and writer occurs. During this time readers comprehend the content and try to compare it with the other source(s), including bringing their schemata on the text. Readers either can accept or reject the idea of the text.

According to Al Naqah (1985:185-186), reading is similar to listening, both are receptive language skills. However, reading is not passive as readers actively process the written message. Reading is a constructive scientific process, namely process to shape new knowledge based on readers' schemata.

Blachowicz (2008:27) explains that readers' knowledge (schemata) can assist them in comprehending new materials. When comprehension takes place, readers activate their schemata. Reading comprehension happens due to one's understanding towards the information read.

Writer and reader build a new knowledge through process of assimilation and accomodation. New information addition on long term memory is produced by the extention process of one's owned knowledge (schemata + reading text $\square$ new knowledge). The process is known as top-down. On the contrary, revising knowledge from reading the text is through 
assimilating the knowledge to schemata (Linda and Soffos, 2005: xii, 20) $\square$ known as bottom-up or similar to reconstructive process. According to Kucer, it is a process of adapting prior knowledge based on new knowledge from the text (2005: 121).

Reading comprehension is influenced by brain metabolism activity on neural area involved in processing raw materials, saving, understanding knowledge through learning, individual connection, prior knowledge, meaning in context mastery, prediction, critical analysis, metacognition (Millis. M D, 2008: 127).

Reading comprehension is the process of rationalizing the reading text by analysing and critisizing it to produce new knowledge by activating all brain cells, assissted by knowledge, experience, and utilizing all abilities.

Thus, comprehending an Arabic reading text is comprehending its content, either implied or explicit, through the process of observation and analysis of the text as well as the use of intelligence in finding the text meaning, content (main idea), and responding the content or information that is found.

\section{c. Comprehension Level}

A number of experts have different opinions in classsifying comprehension level. According to Linda, there are two levels of comprehension, surface and deep (Linda and Carla, 2005:14). Thomas Barrett in Brassell and Rasinsky (2008:17) proposed three levels of reading comprehension: literal, inferential, and critical. According to Blachowicz and Donna (2008:125), competency standard for understanding a text was developed based on the cognitive domain of Bloom's taxonomy, namely knowledge, comprehension, interpretation, application, synthesis, and evaluation, interpreted differently in reading learning context into literal, interpretative, applicative and critical comprehension. These latter comprehension levels are the reference for the action taken in this research.

The indicator for literal comprehension is being able to remember the content and facts in the text, while interpretative comprehension is being able to conclude, develop prior knowledge and experience, grasp new idea from the text, predict or guess correctly, understand what is implied.

To measure one's comprehension, these following question words are used: why, what if, and how. Critical comprehension and application cover the ability to generate critical consideration over text information, analyze, and synthesize, and apply ideas of the text into different situation.

\section{d. Factors Affecting Arabic Reading Skills}

Reading skills are influenced by experience and knowledge pertaining to the reading text (Linda and Carla, 2005:6-7, Tovani, 2000:67). Reading comprehension is initiated by activating background knowledge on the events, people, and place written in the text (Wills MD, 2008 :129) as well as vocabulary mastery (Brasell and Rasinsky, 2008:99). This mastery plays a significant role in one's comprehension of the text. If the words in the text cannot be understood, the text may be uncomprohensible. To comprehend an Arabic text, mastery of Arabic morphology (sorf), nahwu (syntax), vocabularies are needed. 
Without the mastery, readers will not be able to understand the text. The application of SQ4-R in Arabic reading learning also needs to take into account the learning of qira'ah, vocabularies, and grammar.

B. Arabic Reading Learning through SQ4-R

Learning is a specific activity manifested in a class designed consistent or in accordance with methods and approaches chosen (Brown, 2001:14). Richard and Rodgers (cited in White, 1988:2-3) equate technique to procedure, namely 'practical learning stages or steps'.

Technique is part of a learning model that consists of hierarchical series, i.e., approach, strategy, learning method and technique, conducted in implementing a specific method (Directorate General of Islamic Education, 2011:14). In other words, technique is basically concrete and specific learning activity steps selected based on a method or approach that goes in line with the learning purposes or contexts.

Instruction or learning is an oral or written communication between lecturer and students in the form of information delivery or illustration within the field of science or in the form of questions for students, to develop their knowledge, attitude, and skills in an educational environment. The contents of the communication are in a specific domain or parts thereof, and concepts in the communicated area (Seel and Sanne Dijkstra, Ed., 2004:18).

Instruction is a planned effort to provide students with learning activities and experiences that are designed based on their needs and different abilities.(McNamara, Ed., 2005: 61)

Learning should be designed as a service to the students to achieve their mental and physical development maximally and in line with their needs. Therefore, the design has to be based on learning theory, system analysis, research result, and technology development (Morrison et.al, 2007: 6).

It can be concluded that learning means 'lecturer's effort to make students learn to attain their learning goals and her/his effort to cater and guide the students in learning'.

For students, learning technique is a lecturer's concrete and unique steps contextually designed and selected to enable them to achieve concrete learning outcomes.

SQ4-R is reading technique developed from SQ3-R (survey, question, read, recite/recall, review) by Francis P. Robinson in 1941 (Brown, 2004:315; Milan (2004: 5964).

SQ4-R contains work activities and procedure in reading and learning reading, particularly learning to comprehend reading. The purpose is to enable students to read faster and comprehend reading texts. A number of research results on the use of SQ4-R technique show that SQ4-R was eminent in enhancing reading comprehension and learning participation, storing longer learning results, creating more effective learning, shaping efficient reading habit, as well as sustaining learning motivation.

SQ4-R technique tends to be dull if it is done individually. The application of this technique in foreign language teaching requires grammar and vocabulary mastery. 
To overcome the technique's shortcoming, the following steps should be created in learning.

(1) Varied learning environment from individual to group work. The latter to overcome students' weakness in learning foreign language leading to peer tutoring.

(2) Arabic vocabulary mastery conducted through survey, finding word meaning and form in dictionary;

(3) Exercises in applying grammar in reading through a skillful model (peer tutor) and lecturer;

(4) Maintained learning motivation by giving credits and marks based on work result and performance.

Work procedure of Arabic reading learning through the application of SQ4-R technique was conducted as follows.

First, survey: students reviewed reading, title; thought about the tittle and items in the tittle, introduction, first and last paragraph, new words or terms in the reading, finding form and meaning of the words in the dictionary and jotted them down.

Second, question 'creating inquiries', students asked questions as many as they could on the content and wrote them down, for example by converting the tittle and subtitle to interrogative sentences or by using if and WH-question words: what, who, when, why and how.

Third, read, in this stage, students read the content of the chapter, subchapter, even each paragraph in details to get the information from the reading using question guides and results of the vocabulary and meaning survey conducted in the previous stages. Readers find the main idea by reading introduction, summary, first or last paragraph's sentences.

Fourth, recite 'answering inquiries', after reading the text, students answered the proposed questions. The answers were arranged using students' sentences or the language learnt. This stage is a systematical and thorough information storage stage.

Five, rephrase or wRite; students wrote or jotted down in Arabic or Indonesian the main idea of the text, particularly the answers of the questions in the recite stage. In this stage, students can store the information twice (in their brain and in the form of writing), thus notes could be used as a reminder.

Six, review; students reviewed by rereading the text to make sure there were unread information, unanswered questions, and no main ideas that have not been jotted down. Students reread, answered, and wrote down the remaining items (if any).

Reading comprehension was conducted variably within groups or individually using SQ4R technique. Learning with this technique can be broken down into these following activities:

a. pre-reading: covers survey of new vocabularies and meaning in the dictionary (individually or in groups), as well as content of the text, raising questions to explore the text and attain literal and interpretative comprehension, and applicative and critical comprehension;

b. reading, followed by: answering questions and jotting down reading results realized in the form of written language (rephrase) containing text, short explanation of the text based on question list;

c. presenting reading report in the class; 
d. class discusion as the final stage of SQ4-R (review). Test group and individual comprehension at the literal or higher level of comprehension, analyze, and evaluate text information using critical and analytical question list at the question stage (pre-reading stage).

Arabic reading comprehension teaching materials in this research were selected based on (1) appropriateness of content (interesting, and suitable with the learning goals); (2) the ability to facilitate students in attaining reading skills that were integrated with other language skills ; (3) text readability: text challenged the students to learn properly; (4) text should not be too easy or difficult (its vocabularies and sentences (Nuttal, 1989:170-178), be interesting and suitable with the readers' interest and cognitive ability, contained thorough and clear details, attractive illustration, used fusha (Arabic: standard) variety that was easy, appropriate with the students' needs and age, contained vocabularies that went in line with the area learnt, build Islamic moral values, and did not conflict with cultural values (Thu'aimah, 1989: 178-179)

The teaching materials chosen were materials that enabled the students to be skillful in Arabic and teaching Arabic reading at madrasah as well as to enhance their acquisition and knowledge of the language.

Domain for Arabic Reading Comprehension Assessment

Domain for students' Arabic reading skill assessment referred in this study is the development of Bloom's taxonomy that has been revised and combined with Arabic reading skill with the following indicator.

\begin{tabular}{|l|l|}
\hline Comprehension Level & \multicolumn{1}{|c|}{ Comprehension Indicator } \\
\hline 1. Literal comprehension & $\begin{array}{l}\text { Understand what is written in the text in } \\
\text { the form of facts, concepts, procedures } \\
\text { (According to the content of the text). }\end{array}$ \\
\hline $\begin{array}{c}\text { Interpretative } \\
\text { comprehension }\end{array}$ & $\begin{array}{l}\text { Understand what is implied in the text, } \\
\text { conclude, grasp the main idea, predict, } \\
\text { and give opinions. }\end{array}$ \\
\hline $\begin{array}{c}\text { Applicative and } \\
\text { critical comprehension }\end{array}$ & $\begin{array}{l}\text { Analyze, synthesize, apply, an Understand } \\
\text { what is evaluate }\end{array}$ \\
\hline
\end{tabular}

\section{Assessment Instruments}

The instruments used to asses the results of reading learning were test and non test. Among test types, the ones used in this research were short answer test, essay, and daily task portfolio (reading aloud and rephrase).

\section{METHODS}

The aims of this research are to: (1) increase the reading skills of the students in IV semester of the Arabic Education Department, Faculty of Tarbiyah, UIN Raden Intan 
Lampung Academic Year2017 through the application of SQ4-R learning technique; (2) measure the increase of students' skills in reading and comprehending Arabic reading through action learning using SQ4-R technique for 3 cycles.

This research utilized action research. According to Emzir (2008: 234), it is a systematic study on the efforts to improve the educational practice of groups of participants by conducting practical action and reflecting its effect.

Kemmis and Mc Taggart in Denzin and Yvona (2009: 38) use the term collaborative action research and participatory action research (PAR). The scope of the resarch is broad covering the areas of social work, education, industry, and based on varied approaches.

Cherry (2002:1) points out that action research aims to contribute in solving problems quickly and collaboratively to enhance community's knowledge, and is conducted within the framework of mutual benefit.

According to Mertler (2011:5), action reasearch is carried out systematically to increase the quality and effectiveness of the implementation of an activity (learning, education, business, and social change) or for one's own sake.

This research was conducted in the area of education, particularly Arabic reading comprehension learning to improve learning effectiveness and Arabic reading comprehension of the university students in $4^{\text {th }}$ semester, Arabic Education Department, Faculty of Tarbiyah, UIN Raden Intan Lampung Academic Year2017, initiated from April 1, 2012 - July 1, 2013 through the application of SQ4-R learning technique.

Research model used was Hopkin's (2011:55) action research modified from Kemmis' or Lewin's idea on the implementation of cycled action. There is a difference on Hopkin's research, i.e., action research should not start from problems. The most important thing is that it involves the development of idea, does not need to formulate hypothesis as proposed by Kemmis and Taggart. The work procedure includes planning, action, observation and reflection.

Data consist of process and learning outomes. Process data are composed of the improvement of reading skills that originates from the learning process of the researcher, lecturer, and students. Learning outcome data are Arabic reading skills and comprehension based on students' test results at the end of every cycle and daily tasks.

Data gathering was conducted through participant observation, interview, portfolio of students' daily tasks, and field record.

Research instrument was the researcher herself using variety of tools, such as lesson plan, observation guide, interview guide, marking guide for portfolio daily tasks (reading aloud ant rephrase), and reading comprehension test items.

Learning process data were analyzed qualitatively in accordance to Milles and Huberma's opinion in Emzir (2011: 129-135). The analysis consists of: data reduction, data presentation, and data verification as well as conclusion. Learning outcomes in the form of reading comprehension test results were analyzed using simple statistic technique to discover the percentage of students' skill improvement. 


\section{RESULTS AND DISCUSSION}

A. Description of Process, Action, and Result

There are two dimensions of the research result, namely: discoveries on SQ4-R technique application process and learning outcomes in the form of students' Arabic reading skills and comprehension improvement.

Students' participation during the application of SQ4-R technique was high, majority of them actively involved in the learning activity. The details of their activities are as follows.

Individual activities cover:

(1) Pre-reading, students individually :

a. conducted survey: found the meaning of vocabularies in dictionary, surveyed text (tittle, sub tittle, introduction, and important items: numbered, bold or italic text as well as conclusion).

b. created inquiries, generated questions pertaining to the reading content.

(2) Read, read aloud to each other, read in details to find the answers of each other's questions.

(3) Post-reading activities, cover:

a. Recite: answered every proposed question.

b. Wrote down all the answers

Group activities, they consist of:

1) Matching of words, sentences, questions and their answers with the assistance of the head of the group to moderate and organize, share knowledge and meaning among the members.

2) Writing the meaning of words and sentences, questions and correct as well as agreed answers done by each student.

Classical activities.

These activities were composed of:

1) rephrasing, group members rephrased the text orally in front of the class and reviewed each other's rephrasing result.

2) writing and taking the gist of the text from the answers of raised questions.

3) reviewing, in this stage lecturer raised questions to check students reading skills, vocabularies, meaning sentence structure. Review was aimed on the sentence and rephrase results using question technique. Another part of review activities was asking students to reiterate the gist of the text, after 4 meetings the review results were adequate.

Obstacles and Positive Outcome

The obstacles encountered in the learning through SQ4-R were the facts that the students had limited vocabularies, grammar and text related reading experience.

The positive outcome arising from the application of this technique for the lecturer was the development of teaching professionalism as it increased knowledge, enabled a more 
focused teaching, attained learning goals, as well as enhanced lecturer's and students' performance by continuous recreation of lesson plans that were suitable with the class' needs, and fostered new vigor for improvements.

\section{C.2 Learning Outcome Discussion}

The application of SQ4-R technique in Arabic reading comprehension learning experienced modification: the addition of a learning stage, namely finding new words, difficult words, and their meanings in dictionary occurred in the post survey and pre question stage. This new stage is crucial for learning process of reading comprehension of Arabic as a foreign language. This action research generated SVQ4-R (survey, vocabulary, question, read, recite, rephrase, and review) as a modification of SQ4-R.

1. The research results show an increase on students' reading aloud skills and Arabic reading comprehension. Their initial skills merely reached literal comprehension level with an average score of $48,69.7$ in the $1^{\text {st }}$ cycle. 77.68 in the $2^{\text {nd }}$ cycle, and 78.22 in the $3^{\text {rd }}$ cycle. Interpretative comprehension in the beginning of pre-action did not appear, the average score in the $1^{\text {st }}$ cycle was $67,68.4$ in the $2^{\text {nd }}$ cycle, and 73 in the $3^{\text {rd }}$ cycle. The average score of applicative and critical comprehension in the beginning of pre-action had not appeared yet, in the $1^{\text {st }}$ cycle $64.3,70.4$ in the $2^{\text {nd }}$ cycle, and 78.09 in the $3^{\text {rd }}$ cycle.

\section{CONCLUSIONS}

The researcher recommends the understanding of various subjects to apply SQ4-R and SVQ4-R in Arabic or other foreign language learning to enhance: student's comprehension, learning participation, independence, creativity, and innovation. Educational institutions need to facilitate the dissemination and the application of this research result and consider the criteria suitable for their students' that are acceptable with the learning demand and curriculum to overcome learning difficulties.

\section{REFERENCES}

Anggraini, Rika. Meningkatkan Kemampuan Refresentasi Matematik Siswa SMP Melalui Teknik SQ4R (PTK). Tersedia: Digital Library UPI, ETD etd-0201108-153245, perpustakaan@upi.edu (diunduh 6 Pebruari 2010).

Ardiayati, Yati Nur. Pembelajaran Matematika dengan menggunakan Teknik SQ4R dalam Kelompok Kecil sebagai Upaya untuk Meningkatkan Kemampuan Pemecahan Masalah matematika: Studi Eksperimen terhadap Siswa Kelas VIII SMP Negeri 22 Bandung. Tersedia: Digital Library UPI, ETD etd-0201108-153245 (diunduh 6 Pebruari 2010).

Beatrice, S Mikulecky and Linda Jeffries. Reading Power, Second Edition. Francisco: Longman, Inc. 1998.

Blachowicz, Camille, \& Donna Ogle. Reading Comprehension: Strategies for Independent Learners 2nd ed. London: Guilford Press, 2008. 
Brassell, Danny, and Timothy Rasinski. Foreword by Hallie Yopp, Comprehension that Works. Huntington Beach: Shell Education, 2008.

Brenda Smith, Studi Skill: Bahan Ajar on Line. Study Support Centre Cuesta University, Adapted for Breaking Through to College Reading. tersedia pada http://academic.cuesta.edu/ acasupp/as/301 html (diunduh 14 Agustus 2010).

Brown, Douglas, H. Teaching by Principles: An Interactive Approach to Language Pedagogy. Second Edition San Francisco: Longman, 2001.

Brown, H. Douglas. Language Assessment: Principles and Classroom Practices. San Francisco: Longman, 2004.

- Reading Comprehension Strategies: Theories, Interventions, and Technologies. New York: Guilford Press, 2005.

Cherry, Nita. Action Research: a Pathway to Action Knowledge and Learning. Melbourne: RMIT Publishing, 2002.

Cohen, Andrew, D. Assessing Language Ability in Clasroom, Second Edidition. Boston: Heinle and Heinle Publishers, 1994.

Constant,Tina.Teach Yuorself Speed Reading. London: Hodder headline Ltd., 2009.

Cranton, Patricia, Planning Instruction for Adult Leaners. Toronto, Canada: Wall \& Emerson Inc., 1989.

Denzin, Norman, K. and Yvonna S. Lincoln. Hand Book of Qualitatif Research. Terjemahan Daryatno, dkk. Yogyakarta: Pustaka Pelajar, 2009.

Direktorat Jenderal Pendidikan Islam, Strategi dan Model-Model Paikem Materi Pendidikan dan Latihan Guru Pendidikan Agama Islam (Gpai) Tingkat Sekolah Menengah Atas (SMA) dan Sekolah Menengah Kejuruan (SMK). Jakarta: Kementerian Agama Republik Indonesia, 2011.

Djiwandono, M. Soenardi. Tes Bahasa dalam Pengajaran. Bandung: ITB, 1995.

Emzir. Metodologi Penelitian Pendidikan. Jakarta: Rajawali Pers, 2008.

Guthrie, John T., Ed. Motivating Reading Comprehension Concept-Oriented Reading Instruction. New Jersey: Lawrence Erlbaum Associates, Publishers, 2004.

Hirai, Debra L. Cook et al. Grammar Specialists: Academic Language/ Literacy Strategies for Adolescents A "How To" Manual for Educators. First published New York: Routledge 270 Madison Ave, 2010 
Hopkins, David. A Teacher Guide to Classroom Research. Third Edition Buckingham Philadelpia: Open University Press, 2002.

Huffman, Karen et al. Study and Review Guide to Accompany: Psychology In Action. 5th Edition New York: John Wiley \& Sons, Inc, John Wiley \& Sons, Inc , 2000.

Jean, McNiff. Action Research: Principle and Practice. London: Macmillan Education Ltd., 1998.

John T. Guthrie., Ed. Motivating Reading Comprehension Concept-Oriented Reading Instruction, New Jersey, Lawrence Erlbaum Associates, Publishers, 2004.

Kucer, Stephen B. Dimensions of Literacy a Conceptual Base for Teaching Reading and Writing In School Settings. New Jersey London: Lawrence Erlbaum Associates Publishers, 2005.

Linda J. Dorn and Carla Soffos. Teaching for Deep Comprehension: A Reading Workshop Approach. Portland, Maine: Stenhouse Publishers, 2005.

Mc Namara, Danielle S. Ed. Reading Comprehension Strategies: Theories, Interventions, and Technologies. New York: Guilford Press, 2005.

Mc Niff, Jean. Action Research: Principle and Practice. London: Macmillan Education Ltd, 1998

Mertler, Craig A. Action Research: mengembangkan Sekolah dan memberdayakan guru. Alih bahasa oleh Daryatno, Yogyakarta: Pustaka Pelajar, 2011.

Mikulecky, Beatrice S and Jeffries. Reading Power. Second Edition. San Francisco: Longman, Inc. 1998.

Milan, Dianne, K. Developing Reading Skill. New York: Random Hous Inc., 1987.

Moleong, Lexy J. Penelitian Kualitatif. Bandung: Remaja Rosda Karya, 2010

Morrison, et al. Designing Effective Instruction. 5th., Indiana USA: John Wiley and Son, Inc.,2007.

Nuttal, Christine. Teaching Reading Skill in Foreign Language. New Edition Great Britain: Heinemann inc., 1989

Pang, Elyzabeth S. et al. Teaching Reading. Chicago: The International Academyof Education-IAE Unesco, 2003.

Phi Kappa Sigma's Arches. Member Development Manual with SQ4R, Headquarter Phi Kappa Sigma International, Canada: 2002. 
Richards, Jack C, Curriculum Development in Language Teching. Cambridge: Language Teaching Education Press. 2005.

Saha, Lawrence J and A. Gary Dworkin, Ed. International Handbook of Research on Teachers And Teaching. New York: Springer Science LLC, 2009.

Scott G. Paris and Steven A Stahl Ed. Children's Reading Comprehension and Assessment. London: Lawrence Erlbaum Associates, Inc., Publishers, 2005.

Seel, Norbert M. and Sanne Dijkstra, Ed. Curricullum, Plann, And Processes in Instructional Design: International Perspectives. London: Lawrence Erlbaum Associates, 2004.

Smith, Brenda. Studi Skill. Bahan Ajar On Line, Study Support Centre Cuesta University, Adapted for Breaking Through to College Reading 1999. tersedia pada http://academic.cuesta.edu/ acasupp/as/301 html (diunduh 14 Agustus 2010).

Soedarso. Speed Reading: Sistem Membaca Cepat dan Efektif. Jakarta: Gramedia, 2004.

Taba, Hilda, Curriculum Development: Teory and Practice. New York: Haccourt Brace World Inc. 1960.

Tierney, Robert J, et al. Portofolio Assessment in The Reading and Writing Classroom. Gordon: Cristopher Publisher, 1991.

Tim Pengembang Kurikulum dan Silabus, Silabus Mata Kuliah Metode Pengajaran Qiraáh. Bandar Lampung: Fakultas Tarbiyah UIN Raden Intan Lampung, 2008.

Toohey, Susan. Designing Courses for Higher Education.Toronto, Canada: SRHE and Open University Press, 1999.

Tovani, Cris . I Readi It but I Don't Get It. Maine: Stenhouse Publishers, 2000.

White, Ronald V.The ELT Curriculum: Design, Innovation and Management. New York: Basil Blackwell Inc. 1988.

Willis, M.D., Yudi. Teaching the Brain to Read: Strategies for Improving Fluency, Vocabulary, and Comprehension. Virginia USA: Association for Supervision and Curriculum Development, 2008. 


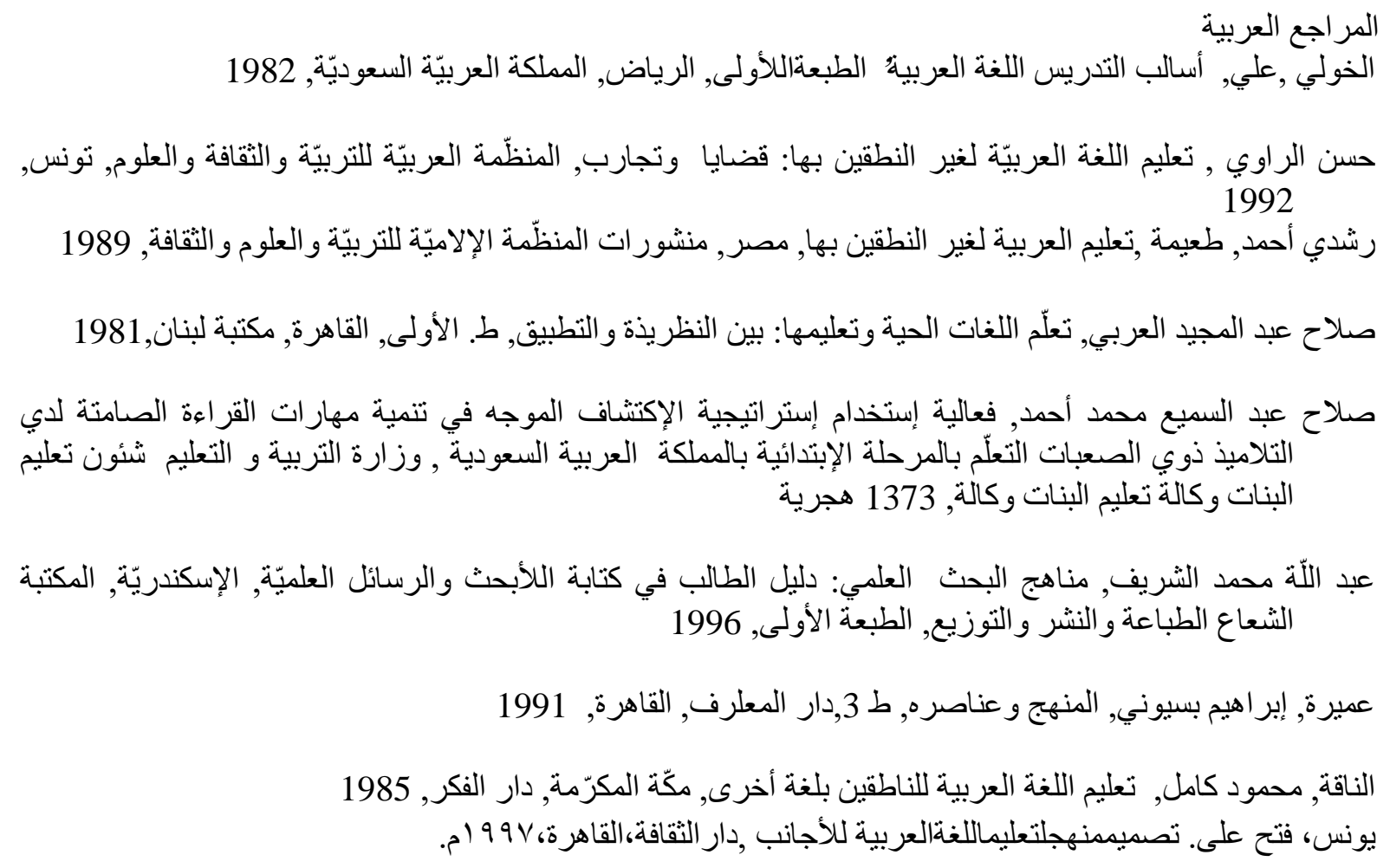

This research is aimed to get a deep understanding towards Japanese learning in 30 Senior High School in Jakarta. This research uses qualitative approach with ethnography method. This research was done in the $9^{\text {th }}$ grade for 4 months, from Dec 2017 until March 2018. The data was gained from observation, interview, field note and documentation right from the location of the research. The data was analysed by using Spradley model, consisting of culture domain, taxonomy, components and theme. The source of research to get the data is from Japanese teacher and all things related with the process of Japanese learning. The 
teacher and students play an important role during the process of learning. The results of the research are: 1) The four objectives which need to be achieved in Japanese learning are : listening skill (choukai), speaking (kaiwa), reading (dokkai), and writing (sakubun) and so that the students have selling point when they are about to work. 2) The curriculum being used is 2013 curriculum. 3) The teaching material being used by the teacher is adjusted with the text book which is sakura book, supporting book and the syllabus. 4) the teaching strategy and the method is lecturing, exercises, assignments based on theme. 5) media used such as tapes, picture cards, learning CD, japanesse language and culture DVD. 6) evaluation of processes and outcomes.

\section{Keywords : Japanese learning, qualitative and ethnography}

Language has a very important role that enables people understand information, express their feelings, develop their knowledge and technology, and culture. It shows that language is a main tool for people communicate both written and spoken language. Therefore, learning foreign languages, such as Japanese language, is very important.

According to Dale, learning is an enduring change in behavior, or in the capacity to behave in a given fashion, which results from practice or other forms of experience. It means that learning is a permanent change or an enduring change in behavior or capacity to behave as the results from practice or past experience or on-going experience (Dale, 2012: 3).

Meanwhile, Gagne, Briggs and Wager state that learning is a series of events that is designed to create a learning process for the students. Learning process depends on all activityiis that directly influence the learners to the process of learning. Thus, interactions amongst the learners are not limited with the presence of teachers in the classroom. Learners may learn from the printed materials, radio programmer, television programmme, and others. However, teachers are still required to plan the learning activities (Gagne, Briggs and Wager, $2005: 3-4,7-8)$.

Japanese language is the most common language used as a means for a Japanese native to communicate and interact with others. The language is also used by Japanese people who live outside Japan for work or other reasons. Besides, it is also used by people who have learnt it.

Okuda in Sudjianto divides the learners in nihongo kyouiku into two types. The ffirst is the learners who learn Japanese language in Japan as a foreign or second language. The second one is people who learn Japanese outside Japan as a foreign language or national language (Sudjianto, $2010: 13$ ).

Learning a foreign language, especially Japanese language, helps learners to develop their communication skills, both written and spoken language. Therefore, English is not the only language that must be taught in schools but also Japanese language. It is worth to teach and, improve learners' knowledge so they are able to use technology, become a creative and smart, and have the identity of Indonesia.

Japanese language is really unique, and able to attract the interest of foreigner learning Japanese language. To learn Japanese language, a competence standardd is required to achieve. It includes four skills; listening (choukai), speaking (kaiwa), reading (dokkai), dan writing (sakubun). According to the data taken from The Japan Foundation, numbers or Japanese learners outside Japan increased, as shown below.

\begin{tabular}{|l|l|l|}
\hline No & Year & Number of \\
\hline
\end{tabular}




\begin{tabular}{|l|l|l|}
\hline & & Learners \\
\hline 1 & 1979 & 127.167 \\
\hline 2 & 1984 & 584.932 \\
\hline 3 & 1988 & 733.802 \\
\hline 4 & 1990 & 981.407 \\
\hline 5 & 1993 & 1.623 .455 \\
\hline 6 & 1998 & 1.102 .103 \\
\hline 7 & 2003 & 2.356 .745 \\
\hline 8 & 2006 & 2.979 .820 \\
\hline 9 & 2009 & 3.651 .232 \\
\hline 10 & 2012 & 3.985 .669 \\
\hline 11 & 2015 & 3.655 .024 \\
\hline
\end{tabular}

Figure 1. Increasing numbers of Japanese Learners outside Japan

Figure 1 shows that the numbers of Japanese learners outside Japan increase every year.

In spite of communication using Japanese language as the effect of the increasing numbers of Japanese learners, Japanese culture cannot be separated from the trends happening in teenagers from primary to high school levels, even university students, such as manga, attract Indonesian citizens to learn Japanese. In addition to that, The Japan Foundation that has strategic place in the city centre, was built by the government to develop the quality of Japanese language education in Indonesia following the national curriculum of Indonesia.

Japanese culture in Indonesia such as Japanese drama, anime, manga, music, harajuku style and also cosplay has aroused a lot of interests and even produced new talents for the learners to learn Japanese language and culture. SMA Negeri 30 has a Japan Club as one of extracurricular activities for students. It is known as Nihon Kazoku (Japanese Family), and guided by Doreyati-sensei, their Japanese teacher. Students in the club do not only learn Japanese language, such as the grammar, and reading, but also Japanese lifestyle, and many kinds of Japanese culture both the traditional and modern one.

A previous study is done by Iriany about English language learning for Second Grade students of SDSD Pondok Kelapa 03 Pagi, East Jakarta. It is a qualitative study using an ethnographic method. The study shows that teacher is able to create a positive learning environment to maximize the learning process. The objective of learning English of this study is to develop English skills based on context, condition and students daily life.

Based on the initial observation done at SMA Negeri 30, East Jakarta, learning process in this school has a unique concept. Teacher delivers the lesson in an easy and fun way. It is understandable by the students so that they are able to apply what they have been learnt in their daily life or school context, for example, ohayou gozaimasu, sensei (Good morning, Ms/Mr), arigatou gozaimasu (thank you).

Learning Japanese language at SMA Negeri 30 is fun, either conducted in the classroom or outside the classroom. Teacher assigned students to list down verbs, nouns, adjectives in Japanese language when watching Japanese drama or anime. Besides students were asked to create a short conversation using the sentence structure that has been taught in 
the classroom. For those reasons, the researcher chose SMA Negeri 30, Jakarta for conducting her research.

SMA Negeri 30 also actively participated for Japanese Festival called "Bunkasai", which is held every year by schools or universities in Jakarta. Students may join a quiz contest, reading competition (dokkai), writing hiragana, katakana or kanji and cosplay competition. Furthermore, SMA Negeri 30 has supporting facilities, such as, Language Lab, various kinds of media for learning, and teachers who are actively participated in Japanese Language Teachers Meeting (MGMP Bahasa Jepang) and also students with good achievement in Japanese language learning.

Japanese language learning at SMA Negeri 30 is also supported by the extracurricular activities. The activities are arranged according to the school curriculum. Students develop their knowledge, interests and skills through the extracurricular activities. The process of Japanese language learning runs smoothly without any distractions, as the activities are planned by the teachers. Moreover, the extracurricular activities of Japanese language at SMA Negeri 30 Jakarta plays a big role to increase students' creativity and intelligence.

Based on the previous explanations, the focus of this study is the learning process of Japanese language learning of for XI grade students at SMA Negeri 30. The deeper study has been done to gain more understanding about the learning process of Japanese language learning, with the sub focus as followed: 1) the objectives of Japanese language, 2) curriculum/syllabus used, 3) learning materials, 4) teaching methods and strategies used in Japanese language learning, 5) teaching media 6) evaluation in language learning 7) cultural themes in Japanese language learning at SMA Negeri 30, Jakarta.

\section{METHODS}

The study used qualitative approach with ethnographic as research method. Ethnography is a process where the researcher is engaged in the research. This study describes and learns values, characters and language of a particular community. Besides, the researcher has to collect data using the interview, observation, note-taking and documentation.

Spradley states that ethnography is a work describing a particular culture. The aim of ethnography is to understand ways of life from the people's perspectives and their relationship with life and realize their vision about the world (Spradley, 1980).

The data is gathered from Japanese language teachers, principal, students at SMA Negeri 30, and from other documents related to Japanese language learning. Observation data is obtained from direct observation of Japanese language learning process of students at SMA Negeri 30, Jakarta, either in the classroom or outside the classroom. Meanwhile, interviews data is collected from the results of discussions and interactions with Japanese language teachers. Furthermore, documentation data is collected from related documents of Japanese language learning, for examples, Japanese language curriculum, syllabus, lesson plan, and other Japanese textbooks used by both teacher and students.

Moreover, the data analysis for this study uses Spradley ways; 1) domain analysis, 2) taxonomy analysis, 3) componential analysis, 4) theme analysis. The data is validated by doing credibility test using extended observation, constant observation, triangulation, and peer discussion.

\section{RESULTS AND DISCUSSION}


Below are the findings and discussions of the study. The findings and discussion were guided by sub-focus presented in the previous chapter and based on the observations, documentation, research note, and interviews.

a. The Aim of Japanese Language Learning

From the observations and interviews, the aim of Japanese language learning in SMA Negeri 30, Jakarta are 1) enable students to master four language skills; listening (choukai), speaking (kaiwa), reading (dokkai), dan writing (sakubun), 2) have more values by having more language skills for their future work.

The aim is set based on the existing curriculum. Students are expected to be able both spoken and written language in any kind of situations, formal or informal, using simple language, so that they are able to communicate by mastering four basic language skills; listening (choukai), speaking (kaiwa), reading (dokkai), dan writing (sakubun), and also gain more knowledge.

According to the aim above, Japanese language learning at SMA Negeri 30 is conducted with developing the four skills but it is set based on the lesson theme and time allocation. Learning process at school will run smoothly with the presence of active, creative, fun, and innovative Japanese language teachers. This motivates and make students have more interests learning Japanese language.

b. Japanese Language Curriculum

SMA Negeri 30 uses Kurikulum 2013 for the Japanese language lesson. It was implemented in SMA Negeri 30, since 2014. The implementation of Kurikulum 2013 guide students to be active in finding information related to the theme that they are going to learn. Kurikulum 2013 is the national curriculum used in Indonesian education system now. It is a fixed curriculum implemented by the government replacing Kurikulum 2006 or is often called Kurikulum Tingkat Satuan Pendidikan (KTSP).

Moreover, from the interviews with Japanese language teachers, the implementation of Kurikulum 2013 is more appropriate with the learning proces at SMA Negeri 30, Jakarta. Syllabus and lesson plan of Japanese language learning at SMA Negeri 30 are designed and composed in line with Kurikulum 2013, and based on students' needs.

c. Japanese Language Learning Materials

Learning materials are the main resources for Japanese language teaching and learning. They make the Japanese language teaching and learning easier both in the classroom and outside classroom, in individual or group. When presenting the learning materials, the teacher selects the materials according to her students' skills, then sets the goal based on Kurikulum 2013.

Japanese language learning materials used in SMA Negeri 30 are;

1) Japanese Language Textbook Sakura Jilid I, II, dan III terbitan The Japan Fondation Jakarta, 2) Japanese Language Textbook Nihongo I dan II published by The Japan Foundation Jakarta, 3) Other supporting book, for instance, vocabulary books, letters book/goi, reading comprehension books/dokkai, and listening books/choukai, 4) Recorded audio and video as the supporting language learning materials of Japanese culture such as life and school in Japan, Japanese songs, and recorded of pronunciation, sentences, and conversations, 5) Picture Flash cards for letters, nouns, adjectives and verbs used according to the materials from The Japan Foundation. 


\section{d. Japanese Language Learning Methods}

Methods and strategies for language learning are needed for teachers in order to achieve the learning objectives. They are also needed for Japanese language learning at SMA Negeri 30 Jakarta. The method is used as a tool for presenting the materials. The approach used in this method is adjusted with Kurikulum 2013. Students are expected to master four skills; listening, speaking, reading, and writing. Therefore, every teacher must have the ability to select the most appropriate learning strategy for the different kinds of learning.

The whole learning process at SMA Negeri 30, Jakarta used communicative approach. However, it should be matched with syllabus and lesson plan. The basic of the communicative approach is students' needs and language function that aims at enabling students to communicate in real situation. Communicative approach is based on students' participations to find out what they want to learn through their learning experiences.

The teacher also used various teaching methods. Story telling method was used when she explained the reading materials (dokkai) since the teacher needed enough time to explain difficult materials which are related to grammatical structure (bunpou) and vocabulary (goi). Teacher explained and asked questions to students about materials that students have been learnt in the textbook. The purpose of this activity is to develop and explore students' knowledge and understanding of the text.

In learning activities, listening (choukai), writing (sakubun), speaking (kaiwa), the method being used is drilling method. Students are asked to listen to vocabulary and dialogue for several times. After that, students were asked to listen to the vocabulary and dialogue that are played several times. Then, they were told to repeat the words, while teacher paid attention to their pronunciation. Afterward, teacher asked students to write down several vocabularies and dialogues in the conversations. Next, they were asked to make their own conversation in Japanese language individually and group, and practiced their conversation in front the classroom. This kind of activity is really helpful for students to be able to practice writing hiragana, katakana, even kanji in order to make students easier to understand to oral text read by the teacher or CD.

\section{e. Instructional Media for Japanese Language Learning}

Media for foreign language learning including Japanese language is needed as one of the learning components. As using media for learning activities is very important, every teacher has to know the advantages of using media in Japanese language and other foreign language learning. Facilities are also connected with media for language learning.

Other supporting facilities for Japanese language learning at SMA Negeri 30, Jakarta, for example Language Lab, has LCD and speaker that are often used for listening and writing. Besides, there is a library providing Japanese textbooks and books about Japanese culture which give advantages for the students learning Japanese language. The school also has a room for s extracurricular activities. For media, using for Japanese language learning in the classroom, teacher uses various kinds of media; provided by the school or media made by the teacher.

Media is used to improve students' skills so that students understand learning materials and motivate students to learn. They are flash cards (e-ka-do / 絵カード), letter 
cards, power point, cassettes, and CD for Japanese language learning, DVD for learning Japanese culture and film (drama and animation).

Media is the most important resource for as helping tools to deliver the materials to students. In conclusion, the function of media is to support the achievement of learning objectives at school. Besides, using the media is hoped to make learning environment become more condusive, fun, active and creative. Media for language learning is something that cannot be separated from Japanese language learning because it raises students' interest and students' motivation to accomplish the learning objectives of Japanese language learning.

\section{f. Evaluation of Japanese Language Learning}

Evaluation is definitely done for language learning. In Japanese language learning, there are two aspects of assessment; process evaluation and results. In process evaluation, students participations are seen from the beginning of the lesson to the end. Meanwhile, result evaluation can be measured from quiz, class test, mid semester test, final test and also practical test. The evaluation is based on the four basic language skills; listening (choukai), speaking (kaiwa), reading (dokkai), and writing (hyouki and sakubun). It is done in order to see the students' improvement to achieve the set objectives.

Evaluation in Japanese language leaning can be assessed from three aspects; 1) cognitive, 2) psychomotor, 3) affective. The evaluation can be done at the end of the learning process are group assignment, class test, and summative test.

\section{CONCLUSIONS}

Based on findings, the conclusion of Japanese language learning in SMA Negeri 30 Jakarta can be made, as follows:

The objective of Japanese language learning is to communicate both verbal and nonverbal in any kind of situations, either formal or informal, using simple language. Therefore, students are proficient in four basic language skills; listening (choukai), speaking (kaiwa), reading (dokkai), and writing (hyouki, sakubun), and also gain knowledge about Japan.

Kurikulum 2013 is really approriate to be used in SMA Negeri 30, Jakarta. Syllabus and lesson plan of Japanese language learning are designed based on Kurikulum 2013 and students' needs. For learning materials, teacher selects the materials first according to students' needs, then set the learning objectives based on Kurikulum 2013. The learning materials are taken from Sakura book, other Japanese language text book, and/or also recorded audio or video.

Meanwhile, teaching methos are used as tools or ways for presenting the materials. The methods should be fit with Kurikulum 2013, in which students must be proficient in four skills: listening, speaking, reading, and writing. The methods should also match with the theme given, for example, for speaking competence use drilling methods, and storytelling for reading. The approach used for Japanese language learning is the communicative approach in order to engage students to be more active and creative. Meanwhile, the role of teacher is as a facilitator. 
Media for language learning is the main resource to present the learning materials to students. Media is used to help teacher delivering the materials. In conclusion, the important function of media is to support the achievement of leaning goals. Various kinds of media are used for language learning, such as, flash cards (e-ka-do / 絵カード), letter cards, power point, cassettes, and CD for Japanese language learning, DVD and other media.

For evaluation of language learning, can be seen from the language activities: students engagement in the class and final score of daily test, written test, practical test.

Overall, it can be concluded that learning process for Japanese language learning in the class or outside the class depends on the media, methods, materials, and others. But the most important thing is the learning process will run smoothly if there is interaction between teachers and students.

\section{REFERENCES}

Gagne Robert M, Leslie J. Briggs and Walter W. Wager. Principles of Intructional Design Fifth Edition, USA: Stratford Publishing Services, Inc, 2005.

Noor Juliansyah. Metodologi Penelitian, Jakarta: Prenada Media Group, 2011

Present Condition of Overseas Japanese Language Education Survey Report on Japanese Language Education Abroad, Tokyo: The Japan Fondation, 2015.

Schunk Dale H. Learning Theories An Educational Perspective, Boston, New york: Pearson, 2012.

Spradley James P. Participant Observation Harcourt Brace Jovanovich College, 1980.

Sudjianto. Metodologi Pembelajaran Keterampilan Berbahasa Jepang, Jakarta: Kesaint Blanc, 2010. 